\title{
Gerhardstorchia nomen novum: a new name for Storchia Dahlmann 2001 (Mammalia: Lipotyphla: Talpidae: Desmaninae)
}

\author{
Thomas Dahlmann $\cdot$ Salih Doğan
}

Received: 20 July 2010/Accepted: 27 July 2010/Published online: 18 August 2010

(C) Springer-Verlag 2010

\begin{abstract}
A junior homonym was detected in a talpid (desmanine) mammalian genus name, and the following replacement name is proposed: Gerhardstorchia nom. nov. for Storchia Dahlmann 2001.
\end{abstract}

Keywords Talpidae $\cdot$ Desmaninae $\cdot$ Storchia .

Nomenclatural change $\cdot$ Homonymy $\cdot$ New name

Kurzfassung Aufgrund der Homonymie zwischen Storchia Oudemans 1923 - vergeben für eine Milben-Gattung, und Storchia Dahlmann 2001-vergeben für eine Gattung der Desmaninae, ist der letztere Name ungültig, so dass vorgeschlagen wird, ihn durch Gerhardstorchia nom. nov. zu ersetzen.

Schlüsselwörter Talpidae $\cdot$ Desmaninae $\cdot$ Storchia . nomenklatorische Änderung · Homonymie · neuer Name

For a new desmanine genus from the Pliocene of Wölfersheim, Dahlmann (2001) proposed the name Storchia, unaware of the fact that this name had been given to Storchia Oudemans 1923, a mite genus (Acari: Raphignathoidea: Stigmaeidae) and is still in use as a valid name. Consequently, Storchia Dahlmann 2001 is a junior homonym of the generic name Storchia Oudemans 1923, and a new name is required

T. Dahlmann $(\bowtie)$

Forschungsinstitut Senckenberg, Senckenberganlage 25,

60325 Frankfurt am Main, Germany

e-mail: thomas.dahlmann@senckenberg.de

S. Doğan

Department of Biology, Kazim Karabekir Education Faculty, Atatürk University, 25240 Erzurum, Turkey

e-mail: sadogan@atauni.edu.tr for the former according to articles 53 and 60 of the International Code of Zoological Nomenclature (International Commission on Zoological Nomenclature 1999).

Again in honour of Dr. Gerhard Storch-Forschungsinstitut Senckenberg, Frankfurt am Main-we propose as a replacement name Gerhardstorchia nom. nov. for the type species from Wölfersheim, Gerhardstorchia wedrevis comb. nov. (Dahlmann 2001) and other species attributed to this genus of fossil desmans thus far: Gerhardstorchia quinquecuspidata comb. nov. (Mayr and Fahlbusch 1975) from Hammerschmiede, Gerhardstorchia sp. from Dorn-Dürkheim, Gerhardstorchia meszaroshi comb. nov. (Sabol 2004) from Devínska Nová Ves (Neudorf), and Gerhardstorchia biradicata comb. nov. (Ziegler 2006) and cf. biradicata from several localities in Austria (Mayr and Fahlbusch 1975; Dahlmann 2001; Sabol 2004; Ziegler 2006).

\section{References}

Dahlmann, T. 2001. Die Kleinsäuger der unter-pliozänen Fundstelle Wölfersheim in der Wetterau (Mammalia: Lipotyphla, Chiroptera, Rodentia). Courier Forschungsinstitut Senckenberg 227: 1-129.

International Commission on Zoological Nomenclature. 1999. International code of zoological nomenclature, 4th ed. London.

Mayr, H., and V. Fahlbusch. 1975. Eine unterpliozäne Kleinsäugerfauna aus der Oberen Süßwasser-Molasse Bayerns. Mitteilungen der Bayerischen Staatssammlung für Paläontologie und historische Geologie 15: 91-111.

Oudemans, J.Th. 1923. Acarologische Aanteekeningen LXXI. Entomologische Berichten 6(130): 145-160.

Sabol, M. 2004. Middle Miocene assemblage of insectivores from Bonanza site near Devínska Nová Ves (Slovakia). Geologica Carpathica 56: 433-445.

Ziegler, R. 2006. Insectivores (Lipotyphla) and bats (Chiroptera) from the Late Miocene of Austria. Annalen des Naturhistorischen Museums in Wien 107A: 93-196. 